\title{
Stock Market Response to Monetary and Fiscal Policy Shocks: Multi- Country Evidence
}

\author{
Ioannis Chatziantoniou ${ }^{1}$, David Duffy ${ }^{2}$, George Filis ${ }^{3 *}$ \\ ${ }^{1,2}$ University of Portsmouth \\ Department of Economics and Finance \\ Richmond Building, Portland Street, PO1 3DE \\ Portsmouth, UK \\ ${ }^{3}$ Bournemouth University \\ Department of Accounting, Finance and Economics \\ The Executive Business Centre, \\ 89 Holdenhurst Road, BH8 8EB \\ Bournemouth, UK \\ *Corresponding author: \\ gfilis@bournemouth.ac.uk, tel:+44 1202 968739, fax:+44 1202968833
}

\begin{abstract}
A Structural VAR model is employed to investigate the effects of monetary and fiscal policy shocks on stock market performance in Germany, UK and the US. A significant number of past studies have concentrated their attention on the relationship between monetary policy and stock market performance, yet only few on the effects of fiscal policy on stock markets. Even more we know little, if any, on the effects of fiscal and monetary policy on stock market performance when the two policies interact. This study aims to fill this void. Our results show that both fiscal and monetary policies influence the stock market, via either direct or indirect channels. More importantly, we find evidence that the interaction between the two policies is very important in explaining stock market developments. Thus, investors and analysts in their effort to understand the relationship between macroeconomic policies and stock market performance should consider fiscal and monetary in tandem rather than in isolation.
\end{abstract}

JEL: C32, G15, E44, E52, E62, H50

Keywords: Monetary Policy, Fiscal Policy, Stock Market, Structural VAR, Fiscal and Monetary Policy Interaction 


\section{Introduction}

The aim of this paper is to examine the effects of fiscal and monetary policy on stock market developments in the UK, the US and Germany. It is widely believed that monetary policy should not be examined in isolation from fiscal policy, and vice versa, as both their individual stances, as well as their interaction, play an important role in the economy and thus, we argue, that they also influence stock market performance. Even though a significant number of past studies have concentrated their attention on the relationship between monetary policy and stock market performance (see, inter alia, Fama and French, 1989; Gertler and Gilchrist, 1993; Jensen and Johnson, 1995; Thorbecke, 1997; Patelis, 1997; Conover, Jensen and Johnson, 1999; Gali and Gertler, 2007; Bjornland and Leitemo, 2009), only few investigate the effects of fiscal policy on stock markets (see, for example, Darrat, 1988; Jansen, Li, Wang and Yang, 2008; Agnello and Sousa 2010; Afonso and Sousa, 2011, 2012). In addition, we know little, if any, on the effects of fiscal and monetary policy on stock market performance when the two policies interact (Jansen et al., 2008). The aim of this study is to fill this void.

Monetary policy authorities in their effort to maintain low inflation will mainly influence the economy's interest rates. This established, it is argued that stances of monetary policy can influence stock market returns via five possible channels, namely (i) the interest rate channel, (ii) the credit channel (iii) the wealth effect, (iv) the exchange rate channel and (v) the monetary channel.

On the other hand, fiscal policy stances can also influence stock market performance. Fiscal policy used in a Keynesian manner can support aggregate demand, boosting the economy and potentially driving stock prices higher. In contrast, classical economic theory focuses on the crowding out effects of fiscal policy in the market for loanable funds and of the productive sectors of the economy. Hence, fiscal policy could potentially drive stock prices lower through the crowding out of private sector activity. Furthermore, from a Ricardian perspective (Barro, 1974, 1979) fiscal policy is impotent and as such will have no effect on stock markets.

However, as aforementioned, the literature in this area of research has neglected the complex relationship between monetary and fiscal policy (Agnello and Sousa, 2010; Darrat, 1988). Examining the effects of monetary policy or fiscal policy on stock market performance is only half of the picture, unless the interaction of the two policies is also considered. This interaction can be rather complex as there are both direct and indirect channels through which fiscal policy could have an impact on monetary policy and vice versa. For example, fiscal policy may interact with monetary policy via (i) the impact of the government inter-temporal 
budget constraint on monetary policy and (ii) the effect of fiscal policy on monetary variables, such as inflation, interest and exchange rates.

In this regard, the main contributions of the paper to the existing literature can be described succinctly. First, we examine the role of both fiscal and monetary policy on stock market performance, considering their interaction, by employing a structural VAR framework. Second, we verify that the contribution of fiscal policy is indeed important and thus it is instructive to be considered in tandem with monetary policy. Third, in contrast with the previous studies we also consider a global demand shock, so as to allow for an exogenous shock to the economies under investigation. In addition, we include an income and a price shock as we consider these to be important in capturing the full dynamics of both monetary and fiscal impulse mechanisms to the stock markets.

In short, results show that both fiscal and monetary policies influence the stock market performance in the countries under investigation, via either direct or indirect channels. More importantly, though, we find evidence that the interaction between the two policies is very important in explaining stock market developments.

The rest of the paper is organised as follows: Section 2 reviews the literature, Section 3 describes the methodology and data used, Section 4 presents the empirical findings of the research and Section 5 concludes the study.

\section{Literature review}

\subsection{Monetary policy and stock market performance}

Stock markets have a multidimensional role to play in connection with monetary policy decision making. On one hand, stock market performance is greatly affected by innovations in monetary policy through several channels, while, on the other hand, stock prices reflect economic developments to a great extent and thus can be considered by monetary policy authorities in the conduct of policy decisions. In this regard, stock market performance not only responds to monetary policy decisions and affects the economy, but also provides feedback to central banks regarding the private sector's expectations about the future course of key macroeconomic variables (Mishkin, 2001).

One of the main channels through which monetary policy propagates the economy is the interest rate channel. This channel suggests that a change in interest rates will have an impact on the corporate cost of capital, which will eventually influence the present value of firms' future net cash flows. Consequently, higher interest rates lead to lower present values of 
future net cash flows, which, in turn, lead to lower stock prices. This channel represents the traditional Keynesian view of the transmission mechanism of interest rates.

Another indirect monetary policy transmission channel, related to interest rate adjustments, is the credit channel. This channel suggests that the central bank can influence the level of investment taking place in a country by altering interest rates. In this regard, it is understood that the level of corporate investment will affect the market value of firms. This argument is predicated upon the fact that the market value of firms is affected by the present value of its future cash flows,. In this sense, higher corporate investment activity should lead to higher future cash flows, thus increasing the firm's market value.

An additional transmission mechanism is via the wealth effect, which suggests that a rise in interest rates will cut the value of long-lived assets, i.e. stock prices. The exchange rate channel also helps explain the way in which interest rates may influence stock prices. In particular, higher interest rates will lead to an appreciation of the domestic exchange rate, resulting in higher imports and lower exports. The latter has a negative effect on the competitiveness of the country, leading to a reduction in production, which will eventually lead to lower asset prices.

Finally, according to Tobin (1969), and the Tobin's Q theory of investment, higher interest rates will lead to lower stock valuation. A more Keynesian approach to Tobin's Q theory, suggests that increased interest rates will cause a transfer of funds from the stock market to the bond market - assuming that only these two assets exist in the market - pushing stock prices down.

For a thorough analysis of the main channels through which stock market prices disseminate monetary policy dynamics on the economy the reader is directed to the theoretical work of Mishkin (2001). Other contributors to this line of research include Bernanke and Gertler (1995), King and Watson (1996), Iacoviello (2005), as well as, Sousa (2010).

In recent years, a growing number of studies have analyzed the effects of monetary policy on financial markets. Authors such as Fama and French (1989), Jensen and Johnson (1995), as well as, Patelis (1997), concentrating particularly on the relationship between monetary policy decisions and stock market performance, argue that the predictability of the latter is greatly influenced by the monetary sector. Thorbecke (1997) and Conover et al. (1999) report a strong positive relationship between expansionary monetary policy and stock market returns. In a similar fashion, Ehrmann and Fratzscher (2004), Rigobon and Sack (2003), and more recently, Sousa (2010) provide evidence that there is a negative relationship between contractionary monetary policy and stock market performance. 
In addition, monetary policy decisions affect stock prices not only through the trade-off between interest gains and stock returns, but also through their influence on investors' expectations. Gali and Gertler (2007), Bjornland and Jacobsen (2008), Bjornland and Leitemo (2009), Kurov (2010), as well as, Castelnuovo and Nistico (2010) maintain that stock market prices are mainly forward looking and contain relevant information regarding expectations about the future. In this regard, monetary policy innovations can greatly affect these expectations.

Pertaining to the readily available information incorporated in the financial markets, Rigobon and Sack (2003) and Bjornland and Leitemo (2009) opine that a reverse positive causation runs from the stock market to monetary policy, as well. By the same token, evidence that asset prices could constitute a source of turmoil and trigger the Central Bank's response can be found in the empirical work of Bernanke, Gertler and Gilchrist (1999) and Bernanke and Gertler (1989, 2000).

Turning to the countries under investigation in this particular study, it is worth noting that Tarhan (1995) and Laopodis (2010) report the absence of a consistent dynamic relationship between US monetary policy actions and US stock market responses. They further argue that the volatile nature of this relationship is mainly the product of changes in monetary policy authorities' operating regimes. Most studies however suggest that there exists a strong negative relationship between monetary policy innovations and stock market performance in the United States. In this respect, Poole and Rasche (2000), Kuttner (2001), Bomfim (2003), as well as, Bernanke and Kuttner (2005), among others, support the view that monetary policy decisions may influence financial markets in more than one way; that is, through their effects on real interest rates, expected future dividends, as well as, expected future stock returns.

As aforementioned, Bjornland and Leitemo (2009) provide strong evidence of a simultaneous interaction, in the short-run, between changes in the monetary policy and stock market returns in the US. To be more explicit, on one hand, positive innovations on interest rates seem to exercise a negative effect on stock market returns, whereas, on the other hand, a positive shock in stock market returns positively affects interest rates. Crowder (2006), reports that positive innovations in the federal funds rate lead to a decline in equity returns. A systematic relationship between monetary policy and stock market returns in the US is also suggested by Becher, Jensen and Mercer (2008). Authors such as Bohl, Siklos and Sondermann (2008) and Kholodilin, Montagnoli, Napolitano and Siliverstovs (2009) have investigated the said 
relationship for four major economies of Europe ${ }^{1}$. In assessing the effects of the European Central Bank's decisions on European financial markets these authors proponent a negative and statistically significant relationship. Bredin, Hyde, Nitzsche, and O'Reilly (2009) on the other hand, report lack of impact of the Euro area monetary policy on German stock returns and attribute this to the longer-term nature of the German stock market compared to other European markets.

With reference to the UK, evidence suggests that there is a strong negative influence of contractionary monetary policy on stock market performance. According to Bredin, Hyde, Nitzsche and O'Reilly (2007), changes in the UK policy rate have a negative and statistically significant effect on FTSE returns. For a thorough explanation of movements in UK's stock returns in connection with monetary policy decisions the reader is directed to the empirical work of Cuthbertson, Hayes and Nitzsche (1999). In short, these authors argue that stock market volatility may very well be attributed to investors' expectations and in particular, to revisions in investors' expectations about future dividends and expected returns.

Finally, Castro and Sousa (2010) provide evidence that both the European Central Bank (ECB) and the Federal Reserve (FED) in formulating their monetary policy framework pay particular attention to the dynamics of financial wealth, whereas, the Bank of England (BoE) mainly considers housing wealth developments.

In retrospect, past evidence tend to favour a negative relationship between changes in monetary policy and stock market developments. In addition, some limited evidence also suggests that stock market changes tend to exert a positive effect on interest rates.

\subsection{Fiscal policy and stock market performance}

The emphasis in the literature on the effects of macroeconomic policy choices on asset prices has focused on the role of monetary policy. Little attention has been paid to the role of fiscal policy in influencing asset prices; some exceptions include Darrat (1988), Jansen et al. (2008), Ardagna (2009) and Afonso and Sousa (2011, 2012). Darrat (1988) notes that "fiscal policy... has been virtually ignored" in representing policy actions which influence stock market returns. More than 20 years later, Agnello and Sousa (2010) second Darrat's argument noting that there is still an "important gap in the literature...regarding the empirical relationship between fiscal policy actions and developments in asset prices" (pp. 2). In light of the current economic crisis and the increasing emphasis on the role of fiscal policy both as a tool of

\footnotetext{
${ }^{1}$ France, Germany, Italy and Spain.
} 
economic stabilisation and a potential source of destabilisation it is increasingly important to gain a better understanding of the effects of fiscal policy on the economy, in general, and the stock market, in particular.

This gap in understanding remains despite the fact that the theoretical effects of fiscal policy on asset markets have been set out since the late 1960s in papers by Tobin (1969), Blanchard (1981) and Shah (1984). Tobin (1969) places an emphasis on the role of the stock market on the relationship between the real and the financial side of the economy. The model set out by Tobin (1969) allows for both monetary and fiscal policy to affect stock market outcomes. Predominantly the discussion on the role of fiscal policy on asset markets focuses on its effects on interest rates and the confidence effects of the long-run sustainability of the budgetary position. Additionally, fiscal policy can influence the level of economic activity, which in turn, will have an impact on stock markets.

From a theoretical perspective, the economic impacts of fiscal policy depend on whether one takes a Keynesian, Classical or Ricardian view of the economy. Keynesian theory sets out the prescription as to the appropriate role of fiscal policy in stabilising economic fluctuations. In particular, similar to automatic stabilisers, discretionary fiscal policy should also act in a countercyclical manner. The mix of discretionary and automatic stabilisers will depend on the extent and composition of the role of government in the economy. Contrary to the Keynesian view of fiscal policy, a Ricardian view stipulates that policy can have no impact on aggregate demand as any public borrowing will be offset by the private savings of rational households. On the other hand, classical economists emphasise that fiscal policy crowds out private sector activity in markets and thus, its effects will be less important in an economy which operates close to its potential output ${ }^{2}$.

Even if demand management can work as set out in the Keynesian framework it is still not taken for granted that fiscal policy makers will use the policy in a stabilising fashion. The practicalities of how fiscal policy is employed will depend upon the political economy environment in which it is made. A political economy approach emphasises that fiscal policy makers are unlikely to use discretionary fiscal policy in a countercyclical fashion; instead the outcome will either be a deficit bias (see, Buchanan and Wagner, 1977; Persson and Svensson, 1989; Tabellini and Alesina, 1990, for example), or procyclical fiscal policy (see, Lane 2003) or even a business cycle driven by fiscal policy shocks (Drazen 2000).

\footnotetext{
${ }^{2}$ Bernheim (1989) provides a review on the Keynesian, Neoclassical and Ricardian views on the effects of the fiscal deficit.
} 
In short, in a theoretical context the economic effects of fiscal policy on the stock market may be positive, negative or inconsequential depending on whether one is to take a Keynesian, Classical or Ricardian view, respectively. The actual application and effects of fiscal policy on stock markets are an empirical matter to be investigated in this paper.

Turning to the empirical evidence on the relationship between fiscal policy and stock markets performance, we have already noted that this is rather limited. In an early study, Darrat (1988) finds that the fiscal deficit ${ }^{3}$ exerts a highly significant negative effect on current stock prices. The research by Agnello and Sousa (2010) also demonstrates that there is an immediate temporary negative response of stock prices to fiscal policy shocks. Afonso and Sousa (2011) consider separately the revenue and expenditure components of the fiscal deficit and find that government expenditure shocks have a negative effect on stock prices, while government revenue shocks have a small and positive effect. Ardagna (2009) finds that fiscal adjustments based on expenditure reductions are related to an increase in stock market prices. Van Aarle et al. (2003) and Laopodis (2010) also provide evidence that fiscal policy matters for stock prices.

Hence, from the foregoing analysis, it is evident that stock markets tend to favour reductions in fiscal expenditure rather than an expansionary fiscal policy.

Nevertheless, so far we were able to extract important conclusions in relation to the effects of monetary and fiscal policy on stock market developments without considering the links between the two demand-side policies. Thus, even though both fiscal and monetary policy has been argued to be important independent policy determinants of stock prices, their impact may also be influenced by the policies' interactions.

For example, Jansen et al. (2008) maintains that the impact of monetary policy on the stock market varies, depending on fiscal policy stance. Thus, research in this area should consider both demand-side policies in a single framework.

\subsection{Fiscal and monetary policy interactions}

The potential conflicting assignments of fiscal and monetary policy give rise to an important strategic interaction between the two policy tools and the institutions in control of the policy leavers. There has been substantial interest in understanding the interactions between monetary and fiscal policy both from a theoretical and empirical perspective. The theoretical literature has focused on the strategic elements of the interaction using tools of game theory,

\footnotetext{
${ }^{3}$ Darrat (1988) measures the fiscal policy stance using the cyclically adjusted fiscal deficit.
} 
while the empirical analysis has focused on the complementarity and strategic substitutability of monetary and fiscal policy.

The interaction arises as both monetary and fiscal policy has implication for the output gap and inflation. We anticipate that the two demand-side policies interact through (i) the impact of government inter-temporal budget constraint on monetary policy and (ii) the effect of fiscal policy on monetary variables, such as inflation, interest and exchange rates (Muscatelli and Tirelli, 2005; Zoli, 2005).

The inter-temporal budget constraint requires that government expenditure is financed through taxation, borrowing or seignorage. Sargent and Wallace (1981) outline the difficulties an unsustainable fiscal policy incurs for monetary policy. In the case of an independent monetary authority implementing a tight monetary policy in response to inflation the "tight money now can mean higher inflation eventually"(Sargent and Wallace 1981, p.2). This arises as deficit financing will eventually require monetary growth leading to higher inflation, when the interest rate is greater than the growth rate of the economy. In this regard, the extent to which the monetary policy can commit and fulfil its duties is rather influenced by fiscal policy decisions. Thus, an insolvent government would render monetary policy weak in dealing with future inflationary pressures (Buti et al., 2001, Sargent, 1999).

An additional implication of an unsustainable fiscal policy is the increased default probability and sovereign risk premium, which can lead to capital outflows and currency depreciation. In the event that the country's debt is mainly denominated in foreign currency, the exchange rate depreciation causes further increase in the country's debt burden. However, this could give rise to a vicious cycle, as the exchange rate depreciation will cause inflationary pressures, which will then require interest rates to increase even further thus, triggering the same succession of the previously mentioned events all over again (Zoli, 2005).

It is further argued (see, Dixit and Lambertini, 2000; Demertzis et al., 1999) that an agreement on the final intentions between the two policies is very important because if the central bank formulates disinflationary policies while the government is engaged in expansionary strategies then final outcomes will deviate significantly from the desired ones.

Empirical investigations into the coordination and interaction of fiscal and monetary authorities assess how they actually behave in practice. Melitz (1997) in his seminal paper finds that monetary and fiscal policy tends to move in opposite directions. In a later paper Melitz (2000, pp.12) interpret this finding as "tightening (easing) of one instrument means less tightening (easing) of the other. Both instruments may still concurrently be tight (or easy as the case may be)". Wyplosz (1999, pp.7) finds that "both attempt to keep inflation in check 
and to conduct countercyclical policies, but each does less when the other moves in the same direction".

Given this actual behaviour of fiscal and monetary authorities and the effects of both policies on stock prices it is important to allow for the interaction of both policies when assessing their impact on stock prices. Afonso and Sousa (2011), as well as, Van Aarle et al. (2003) emphasise the importance of integrating monetary and fiscal policy analysis into one framework in which the interactions and effects of both can be analysed. This is the main aim and contribution of this paper.

\section{Data and methodology description}

\subsection{Data description}

We use quarterly data ${ }^{4}$ from 1991:1 until 2010:4 from three countries, namely Germany, UK and US. The variables under consideration are the global economic activity index, GDP, consumer price index, government expenditure ${ }^{5}$ (as a proxy for fiscal policy stance), M1 (as a proxy for money supply), 3-month interbank rate (as our interest rate instrument) and the stock market indices for these three countries, which are the DAX 30 for Germany, FTSE All Share for the UK and the Dow Jones for the US. The exogenous shock, which is approximated by the global economic activity index (GEA), is based on the dry cargo freight rates and it is constructed by Lutz Kilian (see, Kilian, 2009). All variables are real, seasonally adjusted and are expressed in growth rates.

It is worth noting that there is no consensus in the literature with regards to the identification of the most appropriate measure to capture fiscal policy innovations (i.e. expenditure, taxation or borrowing - see, Afonso and Sousa, 2011). Furthermore, Fatas and Mihov (2001) use changes in government expenditure to capture fiscal policy shocks. There are two advantages of using public expenditure rather than a cyclically adjusted fiscal deficit or tax revenues. Firstly, different theories imply different economic dynamics following a change in public expenditure, while the effects of public revenue changes are qualitatively similar (Fatas and Mihov, 2001). Additionally, focusing on public expenditure does not require modelling the

\footnotetext{
${ }^{4}$ Quarterly data is the highest frequency that will allow the fiscal policy variable to produce meaningful results. Thus, the choice of quarterly data was driven by the frequency of the fiscal policy variable. Furthermore, the use of Industrial Production index reflects only a small part of GDP activity (approximately 30\%) and thus we preferred the use of GDP, which is also available in quarterly frequency.

${ }^{5}$ For the US and UK we use quarterly ESA 1995 accruals based data. The UK government expenditure data is total current expenditure and the US data is primary government expenditure. We have not been able to obtain accruals base data for Germany. The German government expenditure data refers to total general government expenditure.
} 
contemporaneous interaction between taxes and economic activity. The elasticities of government expenditure with respect to output for our sample countries are estimated to be zero according to sources cited in Afonso and Sousa (2009). For these reasons government expenditure is employed in this paper to capture fiscal policy innovations.

A visual representation of the series can be seen in Figures 1 and 2.

\section{[FIGURE 1 HERE]}

[FIGURE 2 HERE]

\subsection{Methodology}

We examine the dynamic relationship among fiscal and monetary policy and the stock market performance, using the SVAR framework. In particular, we consider the following variables in our model: global economic activity, GDP, inflation, government spending, money supply, interest rates and stock market returns. Contrary to the existing literature and given the variations in the conduct of monetary policy outlined in Section 3, we incorporate GDP and inflation to the model in order to capture the full dynamics of both monetary and fiscal policy impulse mechanisms ${ }^{6}$. In addition, a global economic activity index is employed as the exogenous demand variable, capturing the links of the countries under investigation with the world economy, as well as, events of imported inflation ${ }^{7}$.

The structural representation of the VAR model of order $p$ takes the following general form:

$$
\mathbf{A}_{0} \mathbf{y}_{t}=\mathbf{c}_{0}+\sum_{i=1}^{p} \mathbf{A}_{i} \mathbf{y}_{t-i}+\boldsymbol{\varepsilon}_{t}
$$

where, $\mathbf{y}_{t}$ is a $7 \times 1$ vector of endogenous variables, i.e. $\mathbf{y}_{t}=\left[\mathrm{gea}_{t}, y_{t}, \pi_{t}, \mathrm{gov}_{t}, m s_{t}, i_{t}, \mathrm{sm}_{t}\right]$, $\mathbf{A}_{0}$ represents the $7 \times 7$ contemporaneous matrix, $\mathbf{A}_{i}$ are $7 \times 7$ autoregressive coefficient matrices, $\boldsymbol{\varepsilon}_{\mathrm{t}}$ is a $7 \times 1$ vector of structural disturbances, assumed to have zero covariance. The covariance matrix of the structural disturbances takes the following form

\footnotetext{
${ }^{6}$ In this study we use accumulated impulse responses. The motivation for this approach is that fiscal policy tends to have a long-term effect, which can be better shown by the use of accumulated impulses. The accumulative impulse responses have been used in previous studies such as those by Blanchard and Perotti (2002), Ramos and Roca-Segales (2008) and Mountford and Harald (2009).

${ }^{7}$ A number of past studies have used oil prices as a primitive shock in the structure of an SVAR model (Kim and Roubini, 2000; Sims and Zha, 2006; Bjornland and Leitemo, 2009). Nevertheless, as shown by Hamilton (2009a,b) and Kilian (2009), due to the fact that oil prices changes depend on the origin of the oil price shock, their effect is not straightforward. Thus, the use of oil prices as a primitive shock, without identifying the origin of the shock, could be misleading. On the other hand, the Global Economic Activity indicator is a variable that captures world economy fluctuations without having an ambiguous interpretation.
} 
$E\left[\boldsymbol{\varepsilon}_{t} \boldsymbol{\varepsilon}_{t}^{\prime}\right]=\mathbf{D} \equiv\left[\begin{array}{lllllll}\sigma_{1}^{2} & \sigma_{2}^{2} & \sigma_{3}^{2} & \sigma_{4}^{2} & \sigma_{5}^{2} & \sigma_{6}^{2} & \sigma_{7}^{2}\end{array}\right] \times \mathbf{I}$. In order to get the reduced form of our structural model (1) we multiply both sides with $\mathbf{A}_{0}^{-1}$, such as that:

$$
\mathbf{y}_{t}=\mathbf{a}_{0}+\sum_{i=1}^{p} \mathbf{B}_{i} \mathbf{y}_{t-i}+\mathbf{e}_{t}
$$

where, $\mathbf{a}_{0}=\mathbf{A}_{0}^{-1} \mathbf{c}_{0}, \mathbf{B}_{i}=\mathbf{A}_{0}^{-1} \mathbf{A}_{i}$, and $\mathbf{e}_{t}=\mathbf{A}_{0}^{-1} \boldsymbol{\varepsilon}_{t}$, i.e. $\boldsymbol{\varepsilon}_{t}=\mathbf{A}_{0} \mathbf{e}_{t}$. The reduced form errors $\mathbf{e}_{t}$ are linear combinations of the structural errors $\boldsymbol{\varepsilon}_{t}$, with a covariance matrix of the form $E\left[\mathbf{e}_{t} \mathbf{e}_{t}^{\prime}\right]=\mathbf{A}_{0}^{-1} \mathbf{D} \mathbf{A}_{0}^{-1^{\prime}}$.

The structural disturbances can be derived by imposing suitable restrictions on $\mathbf{A}_{0}$. The shortrun restrictions that are applied in this model as the following:

$$
\left[\begin{array}{c}
\varepsilon_{1, t}^{g d s} \\
\varepsilon_{2, t}^{i s} \\
\varepsilon_{3, t}^{p s} \\
\varepsilon_{4, t}^{e s} \\
\varepsilon_{5, t}^{m s s} \\
\varepsilon_{6, t}^{m p t} \\
\varepsilon_{7, t}^{s s}
\end{array}\right]=\left[\begin{array}{ccccccc}
a_{11} & 0 & 0 & 0 & 0 & 0 & 0 \\
a_{21} & a_{22} & 0 & 0 & 0 & 0 & 0 \\
a_{31} & a_{32} & a_{33} & 0 & 0 & 0 & 0 \\
0 & a_{42} & a_{43} & a_{44} & 0 & 0 & 0 \\
0 & a_{52} & a_{53} & a_{54} & a_{55} & 0 & 0 \\
a_{61} & 0 & 0 & a_{64} & a_{65} & a_{66} & a_{67} \\
a_{71} & a_{72} & a_{73} & a_{74} & a_{75} & a_{76} & a_{77}
\end{array}\right] \times\left[\begin{array}{c}
e_{1, t}^{g e a} \\
e_{2, t}^{y} \\
e_{3, t}^{\pi} \\
e_{4, t}^{g o v} \\
e_{5, t}^{m s} \\
e_{6, t}^{i} \\
e_{7, t}^{s m}
\end{array}\right]
$$

where, gds = global demand shocks, is = income shock, ps = price shock, es = government/public expenditure shock, $\mathrm{mss}=$ money supply shock, $\mathrm{mpt}=$ interest rate shock and ss $=$ stock market shock.

The analysis will concentrate on the interaction between the macroeconomic policies and stock market developments. Thus, in the same spirit with Bjornland and Leitemo (2009), we identify the global demand shock, the income shock and the price shock from their respective equations, however these are left, at large, uninterpreted.

The restrictions in our model can be explained, as follows: Income is contemporaneously influenced by an exogenous global demand shock, which is denoted by the global economic activity index, in this study. However, GDP cannot be contemporaneously influenced by any other variable (Kim and Roubini, 2000). On the contrary, it can contemporaneously influence all other variables. Furthermore, inflation reacts contemporaneously only to an income shock and a global demand shock, i.e. imported inflation (Kim and Roubini, 2000; Bjornland, 2008). Both monetary and fiscal policy tools react contemporaneously to income and price shocks (Kim and Roubini, 2000; Afonso and Sousa, 2011), however monetary policy is also 
influenced contemporaneously by the public expenditure shock due to the interaction between the two policies in reaction to income and price shocks (Wyplosz, 1999; Melitz, 2000). Interest rates are influenced contemporaneously by the global demand shock, the public expenditure shock (i.e. we allow for contemporaneous crowing out effects), the money supply shock (Sims and Zha, 2006a,b; Van Aarle et al., 2003; Kim and Roubini, 2000; Elbourne, 2008) and the stock market shock (Bjornland and Leitemo, 2009). Finally, stock market returns are influenced contemporaneously by all variables (Bjornland, 2008).

To proceed to the estimation of the reduced form of model (1), it is first necessary to establish the stationarity of the variables. The ADF and PP unit root tests suggest that all variables are $\mathrm{I}(0)$, as shown in Table 1.

[TABLE 1 HERE]

The order of the VAR model was identified using the Akaike Information Criterion (AIC). The AIC suggested a VAR model of order two. The model does not suffer from autocorrelation or heteroskedasticity, as suggested by the serial autocorrelation LM test, portmanteau joint test and White heteroscedascitity test. Tables 2-5 report the lag length criterion and diagnostic tests.

\section{[TABLE 2 HERE] \\ [TABLE 3 HERE] \\ [TABLE 4 HERE]}

[TABLE 5 HERE]

\section{Empirical Findings}

\subsection{Contemporaneous relationships}

In Table 6 we report the estimated contemporaneous coefficient. The focus of our discussion is on the effects on the stock market.

\section{[TABLE 6 HERE]}

The UK stock market is not contemporaneously influenced by any of the chosen variables. In addition, we observe an interrelationship between monetary and fiscal policy, as this is evidenced by the negative coefficient of $\alpha_{64}$. For both the US and Germany, evidence suggests that their stock markets are positively affected by GDP contemporaneously. For these countries we cannot report any contemporaneous interaction between fiscal and monetary policy. 


\subsection{Accumulated impulse responses}

\subsubsection{United Kingdom}

The results in Figure 3 confirm that both fiscal and monetary policy do affect the stock market in the UK. A positive government expenditure shock causes a decline in the stock market. This finding is in line with Akitoby and Stratmann (2008), Ardagna (2009), Agnello and Sousa (2010) and Afonso and Sousa (2011, 2012). On the monetary policy side, a positive interest rate change causes a decline in the stock market (similar findings were reported for the UK by Bredin et al., 2005). The only other determinant of the stock market, as evidenced from the impulse response functions, is GDP. The stock market reacts favourably to a positive income shock, although this effect is not very significant. This may be due to feedback in the relationship between GDP and the stock market as the latter is shown to be a significant determinant of the former.

\section{[FIGURE 3 HERE]}

In addition, results suggest that fiscal and monetary both react in a countercyclical manner in response to the price level but they fail to react to a GDP shock. The common countercyclical response of both fiscal and monetary policy to the price shock shows that the two policies are being used in a complementary manner, consistent with the findings of Wyplosz (1999), Melits (2000), as well as, Van Aarle et al. (2003).

With reference to interest rates, they seem to react negatively to a fiscal policy shock but do not respond to a money supply shock, as expected. This reaction of the interest rates to fiscal policy is not in the direction consistent with the crowding out hypothesis. The observed inconsistency may be due to the fact that we are considering a public expenditure shock rather a public borrowing shock. This finding can also be interpreted as an additional indirect channel through which fiscal policy affects the UK stock market.

In retrospect, we provide evidence that not only both policies directly affect stock market performance, but also, that the interaction between monetary and fiscal policy is important in explaining stock market developments.

\subsubsection{Germany}

The reaction of the stock market to policy innovations is also evidenced in the case of Germany, as displayed on Figure 4. The German stock market responds positively to money supply growth but fails to respond to government expenditure shocks. The results also suggest that a positive money supply shock puts downward pressure on interest rates. Theoretically, a reduction in interest rates is predicted to have a positive effect on the stock market. In the case 
of Germany, this effect is being captured through money supply and it possibly explains why the interest rate itself is not shown to impact the German stock market. The latter finding is in line with the empirical work of Bredin et al. (2005), who also suggested that the German stock market is not influenced by the interest rates. The fact, that money supply exercises an impact to the stock market, signifies the importance of the money supply inclusion in the model. Given that money supply affects the stock market directly and not via the interest rate channel (although interest rates are affected by money supply changes), is a potential consequence of the fact that Germany does not have its own independent monetary policy authority. Thus, changes in European interest rates may or may not reflect the needs of the individual countries and thus they may or may not exercise a direct affect on their national stock markets. By contrast, if interest rates in Germany were determined by the Central Bank of Germany, we would anticipate the stock market to directly reflect this information.

\section{[FIGURE 4 HERE]}

Furthermore, evidence suggests that income shocks exert a positive effect of the German stock market, whereas price shocks have the opposite impact. There is no evidence that the stock market exercises any effects on the other variables.

Turning to the responsiveness of the policy tools, German fiscal policy is not shown to react to any of the variables, with the exception of inflation. On the other hand monetary policy is shown to be more reactive. Money supply acts in a countercyclical manner to a GDP shock. Additionally, countercyclical monetary policy is evidenced through the positive reaction of the interest rate to innovations in both GDP and the price level.

Overall, we observe that there is no direct effect of fiscal policy on the stock market; however, in its effort to correct output-driven inflationary pressures, public expenditure in Germany seems to exercise an indirect effect on stock market returns. By contrast, money supply has a direct effect on stock market developments which does not pass through the interest rate channel.

\subsubsection{United States}

In relation to the US, a money supply shock negatively influences interest rates, which, in turn, are shown to have a negative impact on the stock market (as shown in Figure 5). Thus, money supply exercises an indirect effect on the US stock market. Furthermore, our findings do not suggest that fiscal policy has any direct effect on the stock market. In addition, positive income shocks lead to higher stock market performance. Turning to the effects of the stock market on other variables, we observe that positive stock market innovations lead to higher 
interest rates, higher GDP, as well as, lower government spending. The bidirectional relationship between the US stock market and the interest rates has also been documented by Bjornland and Leitemo (2009). An interesting finding is that the US stock market performance triggers a positive response in terms of global economic activity. The latter finding signifies the importance of the US stock market in the world economy. This is in line with the theoretical scheme of the financial accelerator, proposed by Bernanke and Gertler (1989) and Bernanke, Gertler and Gilchrist (1999).

\section{[FIGURE 5 HERE]}

Furthermore, the US government spending is shown to exhibit a positive and significant effect on money supply. Having established that there exists an indirect link between money supply and the stock market; this finding provides evidence in favour of an additional indirect link, that between government spending and the stock market.

In addition, interest rates negatively affect the fiscal variable. As in the case of the UK this is an indication that monetary policy and fiscal policy are moving in complementary directions. Thus, the interaction between the two policies is obvious in the case of US, as well.

Although fiscal policy does not determine any other economic or financial variables, it does react to both GDP and interest rate innovations. The positive reaction of government expenditure to GDP can be interpreted as pro-cyclical fiscal policy.

Contrary to fiscal policy, monetary policy is shown to be conducted in a countercyclical manner, as suggested by the response of interest rates to GDP and inflation shocks. In particular, positive GDP shocks raise concerns about higher inflation and increasing interest rates can be considered to be a countercyclical policy.

To summarize, the US stock market reacts to monetary policy and fiscal policy via direct and indirect channels (i.e. monetary policy exercises both a direct (through interest rates) and an indirect impact (through money supply), whereas the fiscal policy exercises only an indirect effect through money supply).

\subsection{Is the fiscal policy variable important?}

In this section we estimate the SVAR model as in equations 1 and 2 using the same identification scheme, although we remove the fiscal policy variable (fiscal-exclusive model $)^{8}$. The purpose of this section is to verify that the incorporation of the fiscal policy in

\footnotetext{
${ }^{8}$ The results regarding the statistical test justifying the exclusion of the fiscal variable are available upon request.
} 
equations 1 and 2 (fiscal-inclusive model) adds significant value to the understanding of stock market innovations. Hence, the short run restrictions are as follows:

$$
\left[\begin{array}{c}
\varepsilon_{1, t}^{g d s} \\
\varepsilon_{2, t}^{i s} \\
\varepsilon_{3, t}^{p s} \\
\varepsilon_{4, t}^{m s s} \\
\varepsilon_{5, t}^{m p t} \\
\varepsilon_{6, t}^{s s}
\end{array}\right]=\left[\begin{array}{cccccc}
a_{11} & 0 & 0 & 0 & 0 & 0 \\
a_{21} & a_{22} & 0 & 0 & 0 & 0 \\
a_{31} & a_{32} & a_{33} & 0 & 0 & 0 \\
0 & a_{42} & a_{43} & a_{44} & 0 & 0 \\
a_{51} & 0 & 0 & a_{54} & a_{55} & a_{56} \\
a_{61} & a_{62} & a_{63} & a_{64} & a_{65} & a_{66}
\end{array}\right] \times\left[\begin{array}{c}
e_{1, t}^{g e a} \\
e_{2, t}^{y} \\
e_{3, t}^{\pi} \\
e_{4, t}^{m s} \\
e_{5, t}^{i} \\
e_{6, t}^{s m}
\end{array}\right]
$$

Focusing on the relationships between interest rates, money supply and stock market we are able to make several important observations and to compare them to the findings of our original model, which incorporated the fiscal policy instrument.

In the case of the UK we observe that in the absence of a fiscal policy instrument, interest rates do not seem to exert a significant impact on stock market developments. Furthermore, contrary to evidence from the fiscal-inclusive model, stock market shocks tend to affect interest rates positively (see Figure 6). In addition, under the fiscal-exclusive model, we cannot claim that neither interest rates nor the stock market respond to a price shock, as it was the case in section 4.2.1.

\section{[FIGURE 6 HERE]}

Turning our attention to the impulse responses for Germany (see Figure 7), we are able to document that stock market responds to interest rate shocks, which is a different finding compared to what was identified in section 4.2.2. Furthermore, under the fiscal-exclusive model, stock market shocks in Germany tend to affect negatively the interest rates; a result opposite to what has been shown in the earlier section.

\section{[FIGURE 7 HERE]}

Finally, Figure 8 shows the impulse responses for the US in the absence of a fiscal policy variable. In the fiscal-exclusive model we observe that the stock market responds negatively to an interest rate shock. In addition the money supply seems to react positively to a stock market shock. These results are different than those reported in section 4.2.3.

\section{[FIGURE 8 HERE]}

In this regard, we are able to suggest that the incorporation of the fiscal policy variable has added significant value to the explanation of stock market developments, considering that 
there are several reactions that are different when the fiscal policy is excluded from the model.

Further robustness checks include altering the order of the policy variables and we also consider long-term interest rates. Results are qualitatively similar for all these alternative approaches 9 .

\section{Conclusion and policy implications}

In this study we use a structural VAR model to investigate the effects of monetary and fiscal policy shocks on stock market performance in Germany, the UK and the US. Using quarterly data for the period 1991:1-2010:4 we find evidence suggesting that both fiscal and monetary policy affect stock market, either directly or indirectly. More importantly, though, we find evidence that the interaction between the two policies is very important in explaining stock market developments.

More specifically, the individual stances of fiscal and monetary policy, as well as their interaction, directly affect the UK stock market developments. With reference to Germany, we cannot find evidence of a direct effect of the fiscal policy on stock market performance, although an indirect effect can be shown, via the interest rate channel. Money supply, on the other hand, appears to have a positive effect on DAX 30, which is not filtered through the interest rate channel. Thus, evidence for Germany suggests that the interaction between fiscal policy and interest rates is also important in explaining innovations in DAX 30. Finally, the US money supply affects interest rates, which in turn negatively affect the stock market. Dow Jones does not appear to receive any direct influence from fiscal policy. Nevertheless, given that a link between fiscal expenditure and money supply is established, we argue that the interaction between fiscal and monetary variables is also important in deciphering the US stock market developments.

The robustness checks stress the importance of incorporating both fiscal and monetary policies in a single framework, as their interaction appears to have a significant contribution to the analysis of stock markets behaviour.

These results have important implications for both investors and analysts as in their effort to understand the relationship between macroeconomic policies and stock market performance they should consider fiscal and monetary policy in tandem rather than in isolation.

\footnotetext{
${ }^{9}$ Results are available upon request.
} 
The identification of the effects of anticipated and unanticipated policies on national stock markets, within the framework of this study, is a promising area for future research. In addition, it is essential that further studies involve the examination of countries with significantly different monetary policies regimes (e.g. countries with exchange rate targeting central bank).

\section{References}

Van Aarle, B., H. Garretsen and N. Gobbin. 2003. Monetary and fiscal policy transmission in the Euro-area: evidence from a structural VAR analysis. Journal of Economics and Business 55: 609-38.

Agnello, L. and R. Sousa. 2010. Fiscal policy and asset prices. NIPE- Universidade do Minho, Working Paper Series, 25/2010.

Afonso, A. and R.M. Sousa. 2011. What are the effects of fiscal policy on asset markets? Economic Modelling 28: 1871-90.

Afonso, A. and R.M. Sousa. 2012. The macroeconomic effects of fiscal policy. Applied Economics 44: 4439-4454.

Afonso, A and R.M. Sousa. 2009. Fiscal policy, housing and stock prices. ECB Working Paper, No. 990.

Akitoby, B. and T. Stratmann. 2008. Fiscal policy and financial markets. Economic Journal 118: 1971-1985.

Ardagna, S. 2009. Financial markets' behaviour around episodes of large changes in the fiscal stance. European Economic Review 53: 37-55.

Barro, R.J. 1974. Are government bonds net wealth? Journal of Political Economy 82: 10951117.

Barro, R.J. 1979. On the determination of public debt. Journal of Political Economy 87: 94071.

Becher, D.A., G.R. Jensen and J.M. Mercer. 2008. Monetary policy indicators as predictors of stock returns. Journal of Financial Research 31: 357-379.

Bernanke, B.S., M. Gertler and S. Gilchrist. 1999. The financial accelerator in a quantitative business cycle framework. In 'Handbook of Macroeconomics: Volume 1C', edited by Taylor, J.B., Woodford, M., Elsevier-North Holland.

Bernanke, B. and M. Gertler. 1989. Agency costs, net worth, and business fluctuations. American Economic Review 79: 14-31. 
Bernanke, B.S. and M. Gertler. 1995. Inside the black box: The credit channel of monetary policy transmission. Journal of Economic Perspectives 9: 27-48.

Bernanke, B.S. and M. Gertler. 2000. Monetary policy and asset price volatility. National Bureau of Economic Research, Working Paper 7559.

Bernanke, B.S. and K.N. Kuttner. 2005. What explains the stock market's reaction to Federal Reserve policy? The Journal of Finance 60: 1221-1257.

Bernheim, B.D. 1989. A neoclassical perspective on budget deficits. Journal of Economic Perspectives 3: 55-72.

Bjornland, H.C. 2008. Monetary policy and exchange rate interactions in a small open economy. Scandinavian Journal of Economics 110: 197-221.

Bjornland, H.C. and D.H. Jacobsen. 2008. The role of house prices in the monetary transmission mechanism in the U.S. Norges Bank, Working Paper No. 2008/24.

Bjornland, H.C. and K. Leitemo. 2009. Identifying the interdependence between US monetary policy and the stock market. Journal of Monetary Economics 56: 275-282.

Blanchard, O.J. 1981. Output, the stock market and interest rates. American Economic Review 71: 132-43.

Blanchard, O. J. and R. Perotti. (2002) An empirical characterization of the dynamic effects of changes in government spending and taxes on output, Quarterly Journal of Economics, 117, pp. 1329-68.

Board of Governors of the Federal Reserve System. 2005. Federal Reserve System: Purposes and Functions ( $9^{\text {th }}$ edition), Wasington D.C.

Bohl, M.T., P.L. Siklos and D. Sondermann. 2008. European stock markets and the ECB's monetary policy surprises. International Finance 11: 117-130.

Bomfim, A.N. 2003. Pre-announcement effects, news effects and volatility: Monetary policy and the stock market. Journal of Banking and Finance 27: 133-151.

Bredin, D., S. Hyde, D. Nitzsche and G. O'Reilly. 2007. UK stock returns and the impact of domestic monetary policy shocks. Journal of Business Finance and Accounting 34: 872-888.

Bredin, D., S. Hyde, D. Nitzsche and G. O’Reilly. 2009. European monetary policy surprises: The aggregate and sectoral stock market response. International Journal of Finance and Economics 14: 156-171.

Buchanan, J.M. and R.E. Wagner. 1977. Democracy in deficit: The political legacy of Lord Keynes. New York: Academic Press. 
Buti, M., Roeger, W., and J.I. Veld. 2001. Stabilising output and inflation: Policy conflicts and co-operation under a stability pact. Journal of Common Market Studies 39: 801-28.

Castelnuovo, E. and S. Nisticò. 2010. Stock market conditions and monetary policy in a DSGE model for the U.S. Journal of Economic Dynamics and Control 34: 1700-1731.

Castro, V. and R.M. Sousa. 2010. How do central banks react to wealth composition and asset prices? University of Minho, Economic Policies Research Unit (NIPE), Working Paper 26.

Chari, V.V., and P.J. Kehoe. 1998. On the need for fiscal constraints in a monetary union. Federal Reserve Bank of Minneapolis, Working Paper No. 589.

Conover, C.M., G.R. Jensen, R.R. Johnson and J.M. Mercer. 1999. Monetary environments and international stock returns. Journal of Banking and Finance 23: 1357-1381.

Crowder, W.J. 2006. The interaction of monetary policy and stock market returns. Journal of Financial Research 29: 523-535.

Cuthbertson, K., S. Hayes and D. Nitzsche. 1999. Explaining movements in UK stock prices. The Quarterly Review of Economics and Finance 39: 1-19.

Darrat, A. 1988. On fiscal policy and the stock market. Journal of Money Credit and Banking 20: 353-363.

Demertzis, M., Hughes Hallett, A.J., and N. Viegi. 1999. An independent central bank faced with elected governments. CERP Discussion Paper No. 2219.

Dixit, A., and L. Lambertini. 2000. Symbiosis of monetary and fiscal policies in a monetary union. Princeton / UCLA, Working Paper, March.

Drazen, A. 2000. The political business cycle after 25 years. NBER Macroeconomics Annual 15: $75-117$.

Ehrmann, M. and M. Fratzscher. 2004. Taking stock: Monetary policy transmission to equity markets. European Central Bank, Working Paper 354.

Elbourne, A. 2008. The UK housing market and the monetary policy transmission mechanism: An SVAR approach. Journal of Housing Economics 17: 65-87.

Fama, E.F. and K.R. French. 1989. Business conditions and expected returns on stocks and bonds. Journal of Financial Economics 25: 23-49.

Fatas, A. and I. Mihov. 2001. The effects of Fiscal Policy on consumption and employment: Theory and evidence. CEPR Discussion Paper, 2760.

Gali, J. and M. Gertler. 2007. Macroeconomic modeling for monetary policy evaluation. Journal of Economic Perspectives 21: 25-45. 
Gertler, M. and S. Gilchrist. 1993. The role of credit market imperfections in the transmission of monetary policy: Argument and evidence. Scandinavian Journal of Economics 95: 43-64.

Hamilton, J.D., 2009a. Understanding crude oil prices. Energy Journal 30, 179-206.

Hamilton, J.D., 2009b. Causes and consequences of the oil shock of 2007-08. Brookings Papers on Economic Activity Spring 2009, 215-261.

Iacoviello, M. 2005. House prices, borrowing constraints and monetary policy in the business cycle. American Economic Review 95: 739-764.

Jansen D.W., Q. Li, Z. Wang and J. Yang. 2008. Fiscal policy and asset markets: A Semiparametric analysis. Journal of Econometrics 147: 141-150.

Jensen, G.R. and R.R. Johnson. 1995. Discount rate changes and security return in the U.S., 1962-1991. Journal of Banking and Finance 19: 79-95.

Kholodilin, K., A. Montagnoli, O. Napolitano and B. Siliverstovs. 2009. Assessing the impact of ECB's monetary policy on stock markets: A sectoral view. Economics Letters 105: 211-213.

Kilian, L. 2009. Not all oil price shocks are alike: Disentangling demand and supply shocks in the crude oil market. American Economic Review 99: 1053-1069.

Kim S. and N. Roubini. 2000. Exchange rate anomalies in the industrial countries: A solution with a structural VAR approach. Journal of Monetary Economics 45: 561-586.

King, R.G. and M.W. Watson. 1996. Money, prices, interest rates and the business cycle. The Review of Economics and Statistics 78: 35-53.

Kurov, A. 2010. Investor sentiment and the stock market's reaction to monetary policy. Journal of Banking and Finance 34: 139-149.

Kuttner, K.N. 2001. Monetary policy surprises and interest rates: Evidence from the Feds fund future market. Journal of Monetary Economics 47: 523-544.

Lane, P. 2003. The cyclical behaviour of fiscal policy: evidence from the OECD. Journal of Public Economics 87: 2661-2675.

Laopodis, N. 2010. Dynamic linkages between monetary policy and the stock market. Review of Quantitative Finance and Accounting 35: 271-293.

Melitz, J. 1997. Some cross-country evidence about debt, deficits and the behaviour of monetary and fiscal authorities. CEPR Discussion Paper, No. 1653, CEPR, London.

Melitz, J. 2000. Some cross-country evidence about fiscal policy behaviour and consequences for EMU. European Economy Reports and Studies 2: 3-21. 
Mishkin, F.S. 2001. The transmission mechanism and the role of asset prices in monetary policy. National Bureau of Economic Research, Working Paper 8617.

Mountford A. and U. Harald (2009) "What are the effects of fiscal policy shocks?", Journal of Applied Econometrics, 24, pp. 960-992

Muscatelli, V.A., and P. Tirreli. 2005. Analyzing the interaction of monetary and fiscal policy: Does fiscal policy play a valuable role in stabilisation? CESifo Institute for Economic Research, CESifo Economic Studies 51: 549-585.

Patelis, A.D. 1997, Stock return predictability and the role of monetary policy. Journal of Finance 52: 1951-72.

Persson, T. and L.E.O. Svensson. 1989. Why a stubborn conservative would run a deficit: Policy with time inconsistent preferences. Quarterly Journal of Economics 104: 325345 .

Poole, W. and R.H. Rasche. 2000. Perfecting the market's knowledge of monetary policy. Journal of Financial Services Research 18: 255-298.

Ramos X. and Roca-Sagales O. (2008) Long-term effects of fiscal policy on the size and distribution of the pie in the UK, Fiscal Studies, 29(3), pp. 387-411.

Rigobon, R. and B. Sack. 2003. Measuring the response of monetary policy to the stock market. Quarterly Journal of Economics 118: 639-669.

Sargent, T.J. 1999. A primer on monetary and fiscal policy. Journal of Banking and Finance 23: $1463-1482$.

Sargent, T. and N. Wallace. 1981. Some unpleasant monetarist arithmetic. Federal Reserve Bank of Minneapolis Quarterly Review Fall: 1-17.

Shah, A. 1984. Crowding out, capital accumulation, the stock market, and money-financed fiscal policy. Journal of Money, Credit, and Banking 16: 461-473.

Sims, C. and T. Zha. 2006a. Were there regime switches in U.S. monetary policy? American Economic Review 96: 54-81.

Sims, C.A. and T. Zha. 2006b. Does monetary policy generate recessions? Macroeconomic Dynamics 10: 231-272.

Sousa, R.M. 2010. Housing wealth, financial wealth, money demand and policy rule: Evidence from the Euro area. The North American Journal of Economics and Finance 21: $88-105$.

Tabellini, G. and A. Alesina. 1990. Voting on the budget deficit. American Economic Review 80: 37-49. 
Tarhan, V. 1995. Does the Federal Reserve affect asset prices? Journal of Economic Dynamics and Control 19: 1199-1222.

Thorbecke, W. 1997, On stock market returns and monetary policy. Journal of Finance 52: 635-54.

Tobin, J. 1969. A general equilibrium approach to monetary theory. Journal of Money, Credit and Banking 1: 15-29.

Wyplosz, C. 1999. Economic policy coordination in EMU: Strategies and institutions. Presented at the German-French Economic Forum in Bonn. Available from http://hei.unige.ch/ wyplosz/cw_bonn_final.PDF.

Zoli, E. 2005. How does fiscal policy affect monetary policy in emerging market countries? Bank of International Settlements, Working Papers No. 174. 
Figures

Figure 1: Global Economic Activity Index

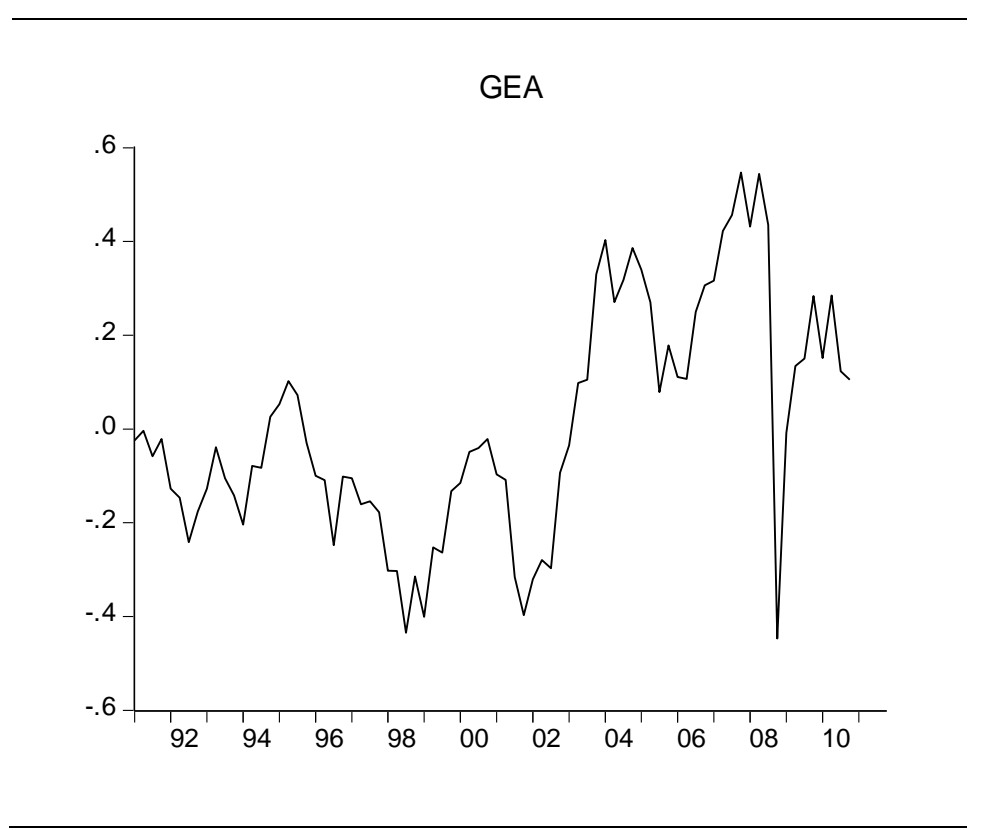


Figure 2: Growth rates of variables for Germany, UK and US

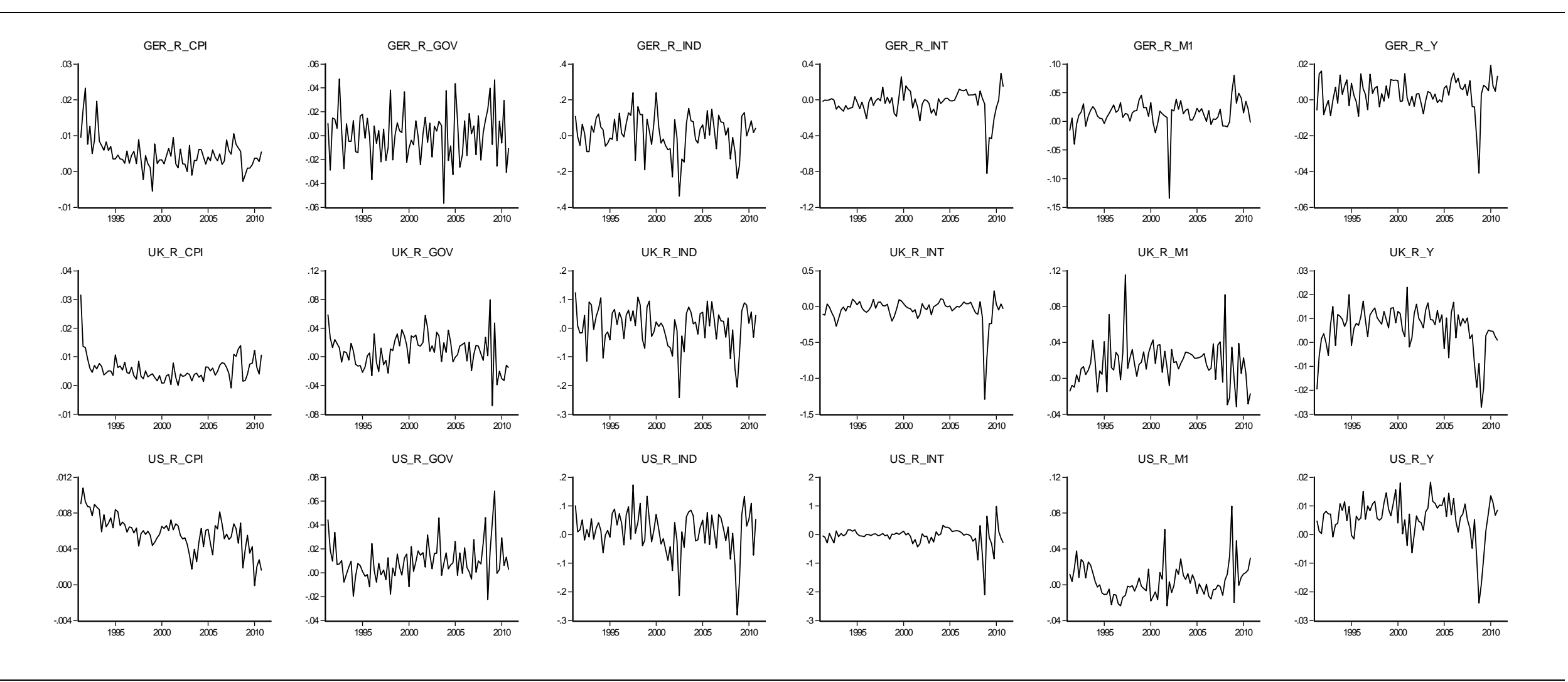


Figure 3: Accumulated Impulse Responses - Fiscal-Inclusive Model - UK

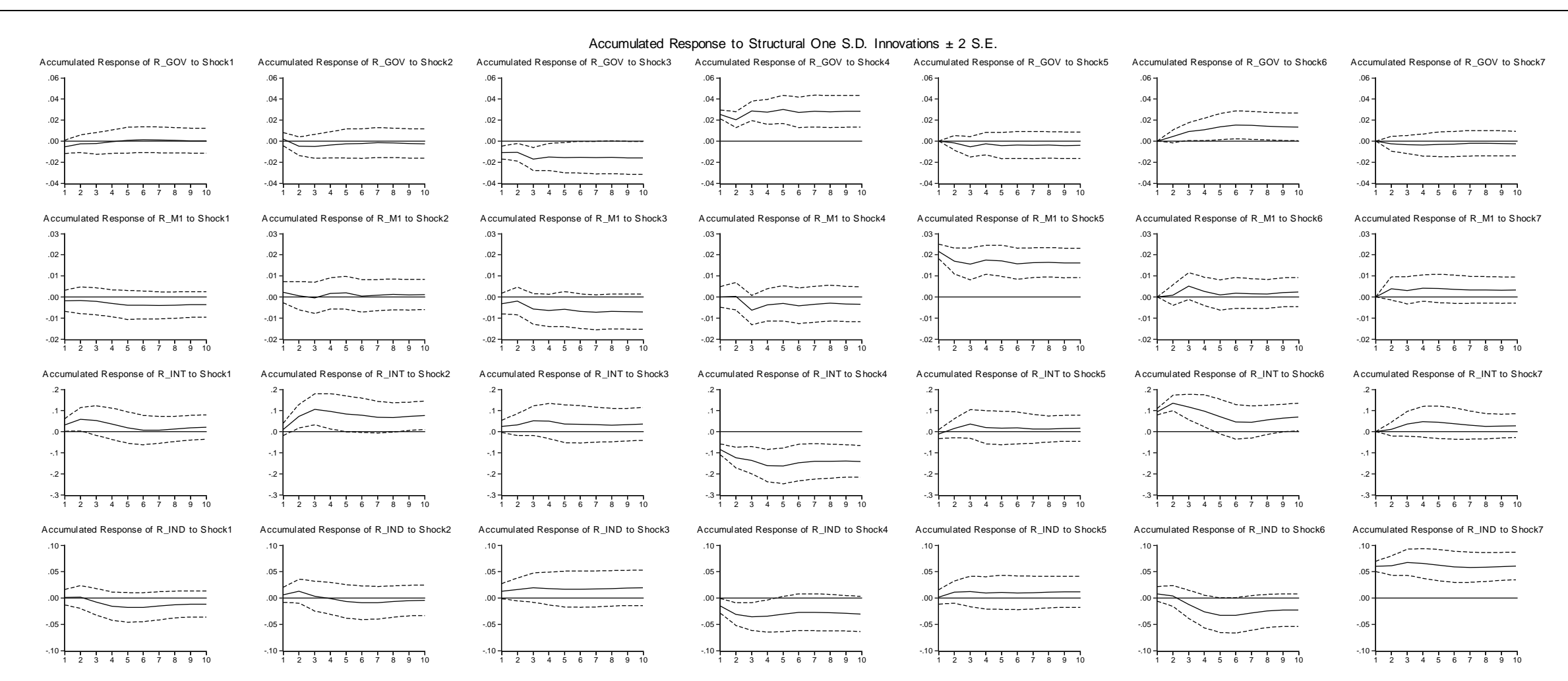

Note: Shocks 1, 2, 3, 4, 5, 6 and 7 refer to shocks from global economic activity, gdp, inflation, government expenditure, money supply, interest rates and stock market, respectively. 
Figure 4: Accumulated Impulse Responses - Fiscal-Inclusive Model - Germany

Accumulated Response to Structural One S.D. Innovations \pm 2 S.E.
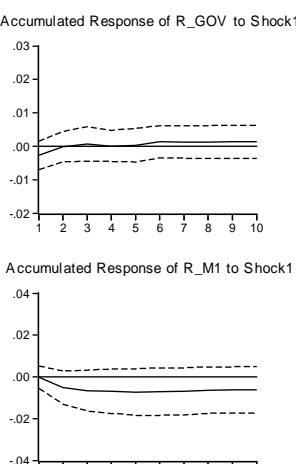

$.04-\frac{1}{1}$\begin{tabular}{lllllllll}
1 & 1 & 1 & 1 & 1 & 1 & 1 & 1 \\
\hline & 3 & 4 & 5 & 6 & 7 & 8 & 9 & 10
\end{tabular}

Accumulated Response of R_INT to Shock1

${ }^{4-1}$

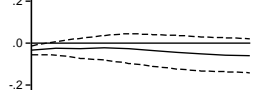

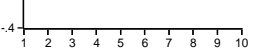

Accumulated Response of R_IND to Shock1

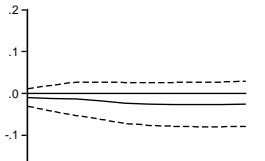

$\begin{array}{llllllllllll}-1 & 2 & 1 & 4 & 1 & 1 & 1 & 1 & 1 & 1 & 10\end{array}$
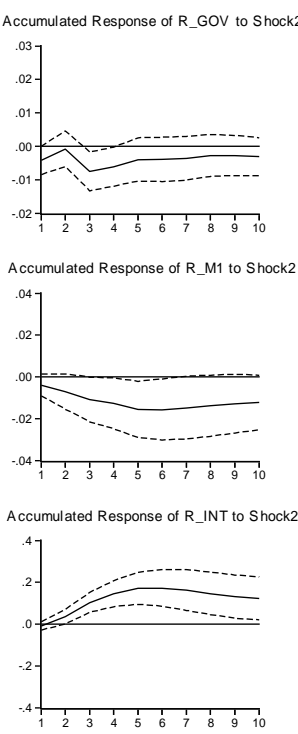

Accumulated Response of R I IND to Shock

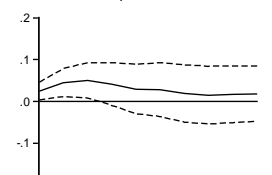

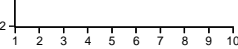
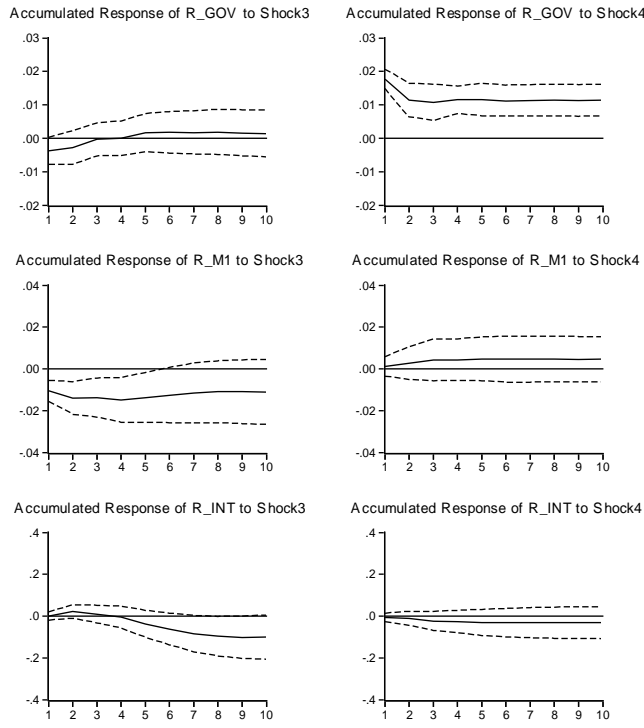

Accumulated Response of R IND to Shocis

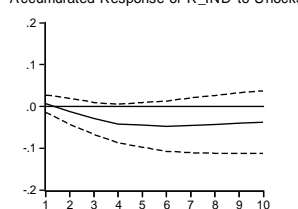

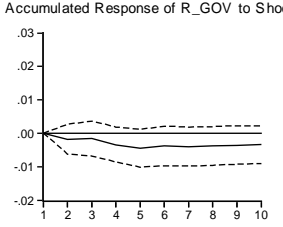

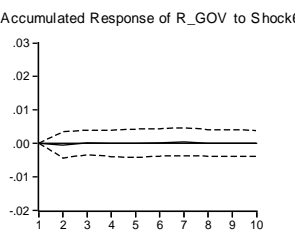

Accumblated Response of R_GoV to Shock7
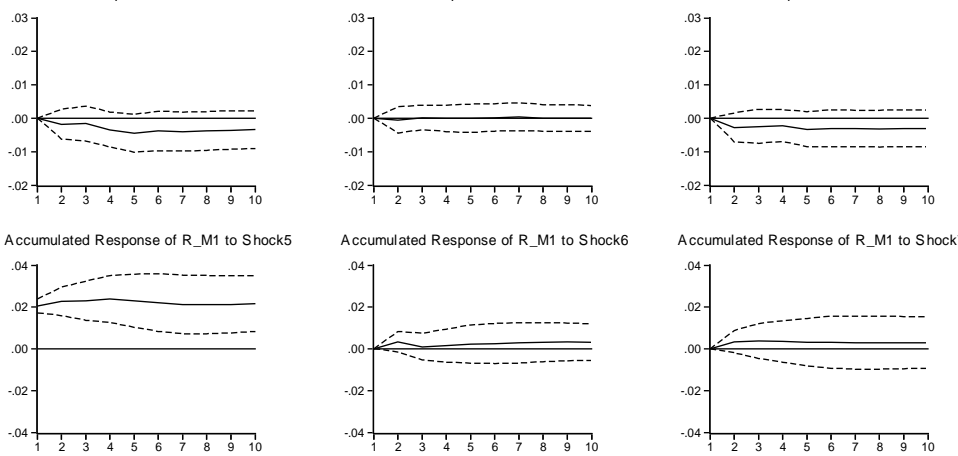

Accumulated Response of R_M1 to Shock?

.04

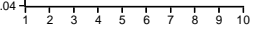

Accumulated Response of R_INT to Shoock

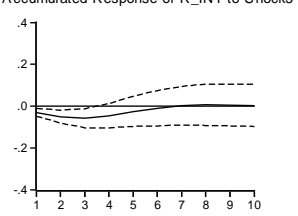

$\begin{array}{lllllllllll}1 & 2 & 3 & 4 & 5 & 6 & 7 & 8 & 1 & 1 & 10\end{array}$

Accumulated Response of R_IND to Shooks

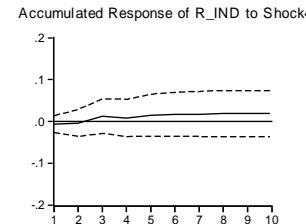

Accumulated Response of R_INT to Shock6

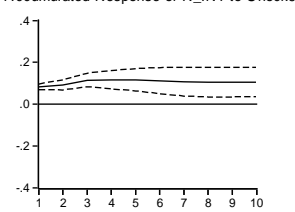

Accumulated Response of $R$.ND to Shocit

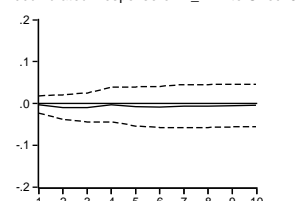

$02-10$

00

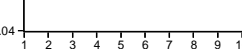

Accumulated Response of R_INT to Shook

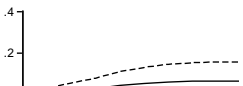

-

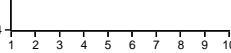

Accumulated Response of R_IND to Shock

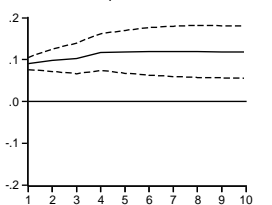

Note: Shocks 1, 2, 3, 4, 5, 6 and 7 refer to shocks from global economic activity, gdp, inflation, government expenditure, money supply, interest rates and stock market, respectively. 
Figure 5: Accumulated Impulse Responses - Fiscal-Inclusive Model - US

Accumulated Response to Structural One S.D. Innovations \pm 2 S.E.

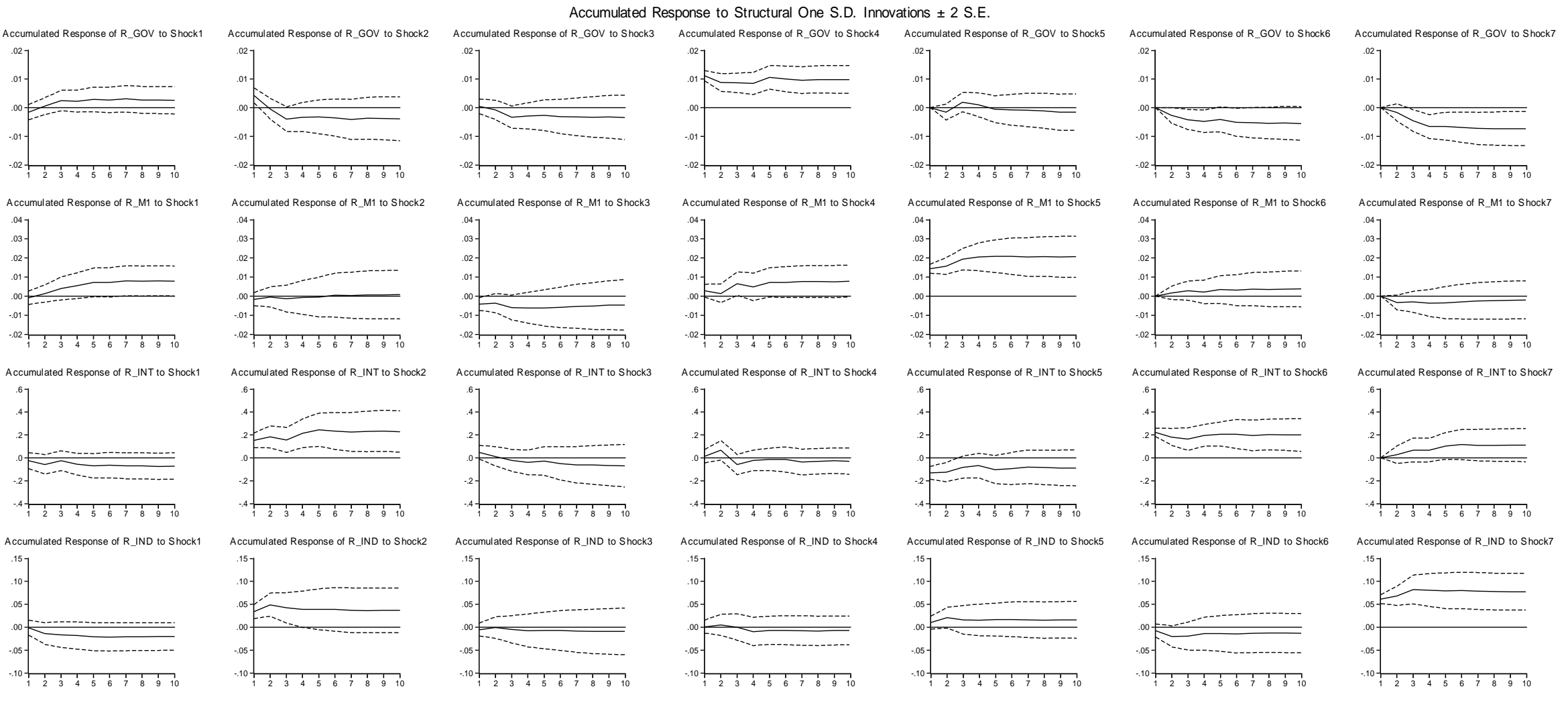

Note: Shocks 1, 2, 3, 4, 5, 6 and 7 refer to shocks from global economic activity, gdp, inflation, government expenditure, money supply, interest rates and stock market, respectively. 
Figure 6: Accumulated Impulse Responses - Fiscal-Exclusive Model - UK

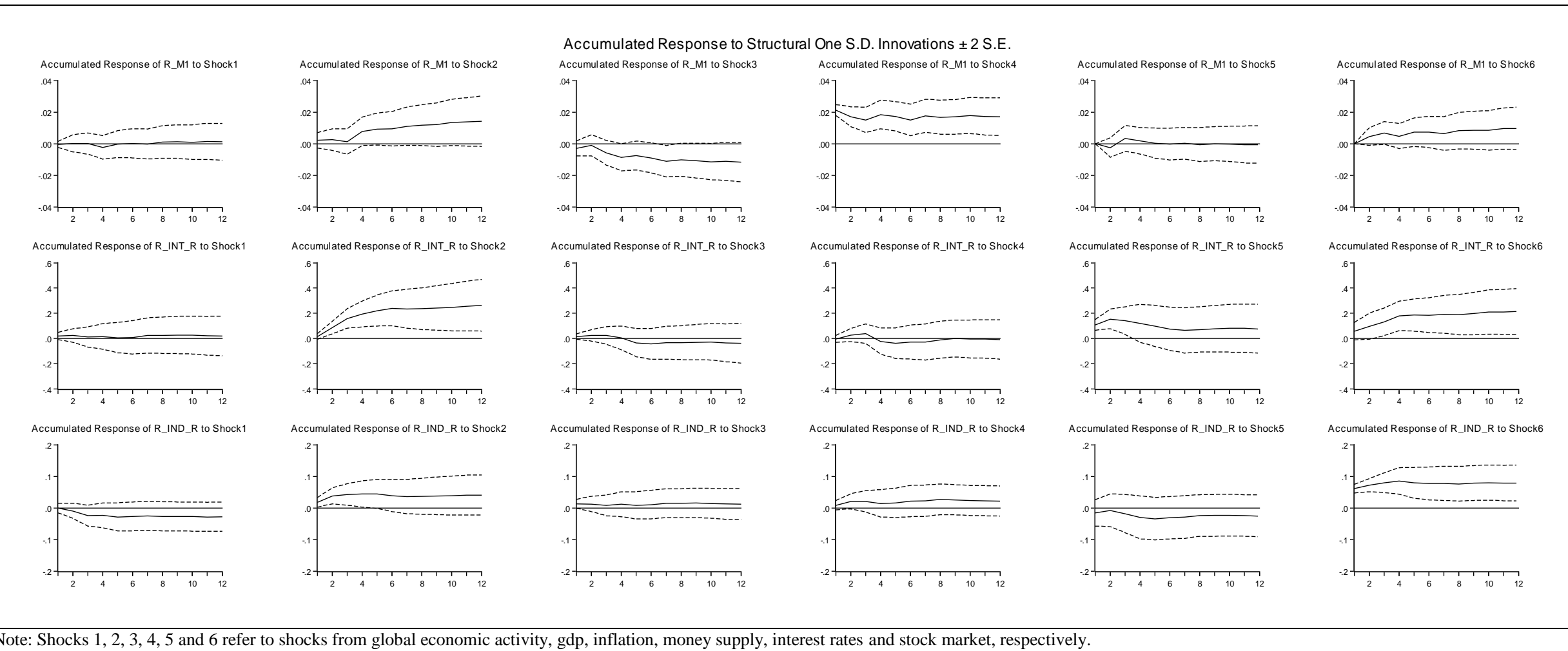

Note: Shocks 1, 2, 3, 4, 5 and 6 refer to shocks from global economic activity, gdp, inflation, money supply, interest rates and stock market, respectively. 
Figure 7: Accumulated Impulse Responses - Fiscal-Exclusive Model - Germany

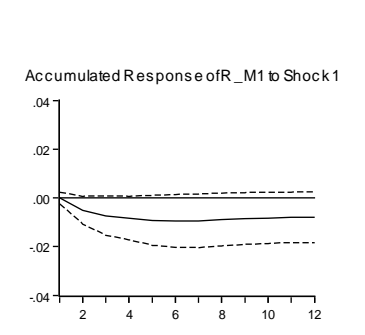

Accumulated Response ofR_INT_R to Shock1

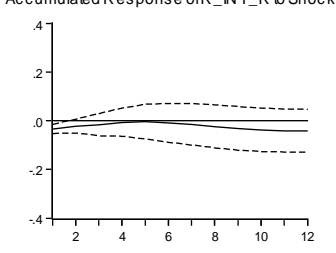

Accumulated Response ofR_IND_R to Shock1

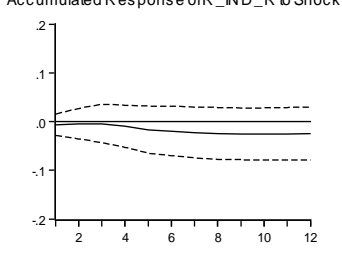

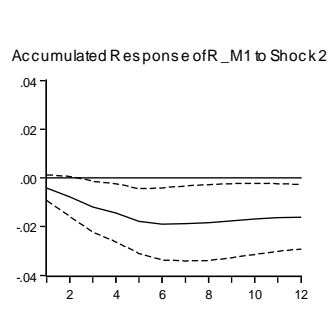

Accumulated Response ofR_INT_R to Shock2
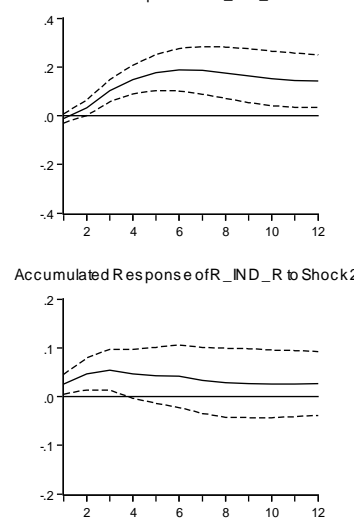

Accumulated Response to Structural One S.D. Innovations \pm 2 S.E. Accumulated Response ofR_M1 to Shock3 Accumulated Response ofR_M1 to Shock4

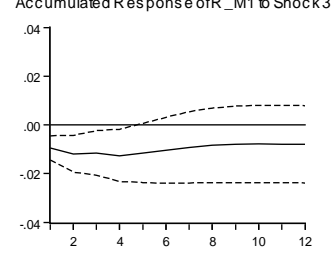

Accumulated Response ofR_INT_R to Shock3

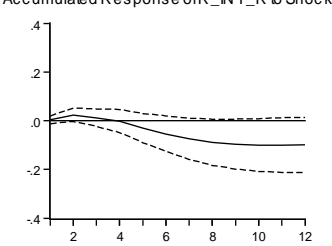

Accumulated Response ofR_ND_R to Shock3

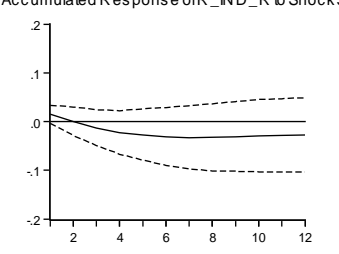

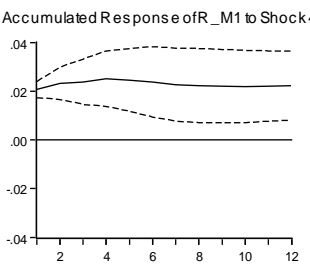

Accumulated Response ofR_NT R to Shock

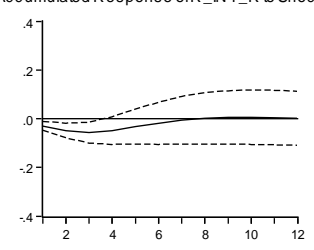

Accumulated Response ofR_ND_R to Shock

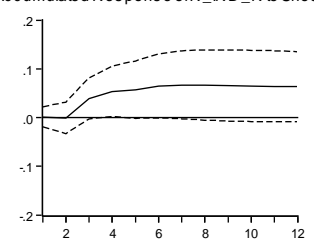

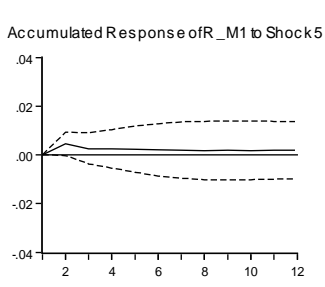

Accumulated Response ofR_INT R to Shock 5

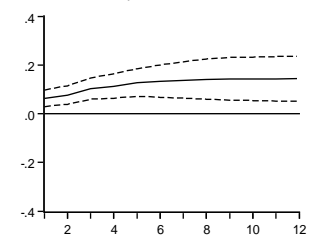

Accumulated Response ofR_IND_R to Shook5

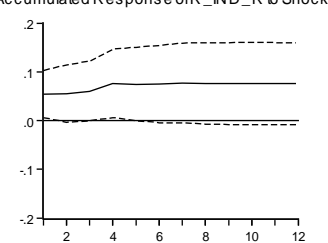

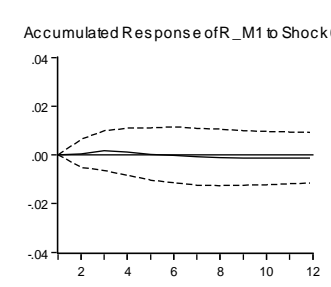

Accumulated Response ofR INT R to Shock 6

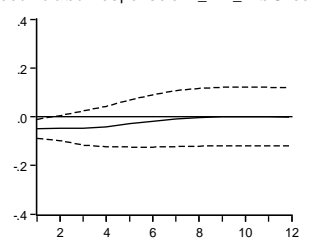

ACanuted Response ofR_IND_R R t Shock

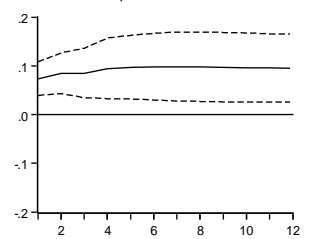

Note: Shocks 1, 2, 3, 4, 5 and 6 refer to shocks from global economic activity, gdp, inflation, money supply, interest rates and stock market, respectively. 
Figure 8: Accumulated Impulse Responses - Fiscal-Exclusive Model - US

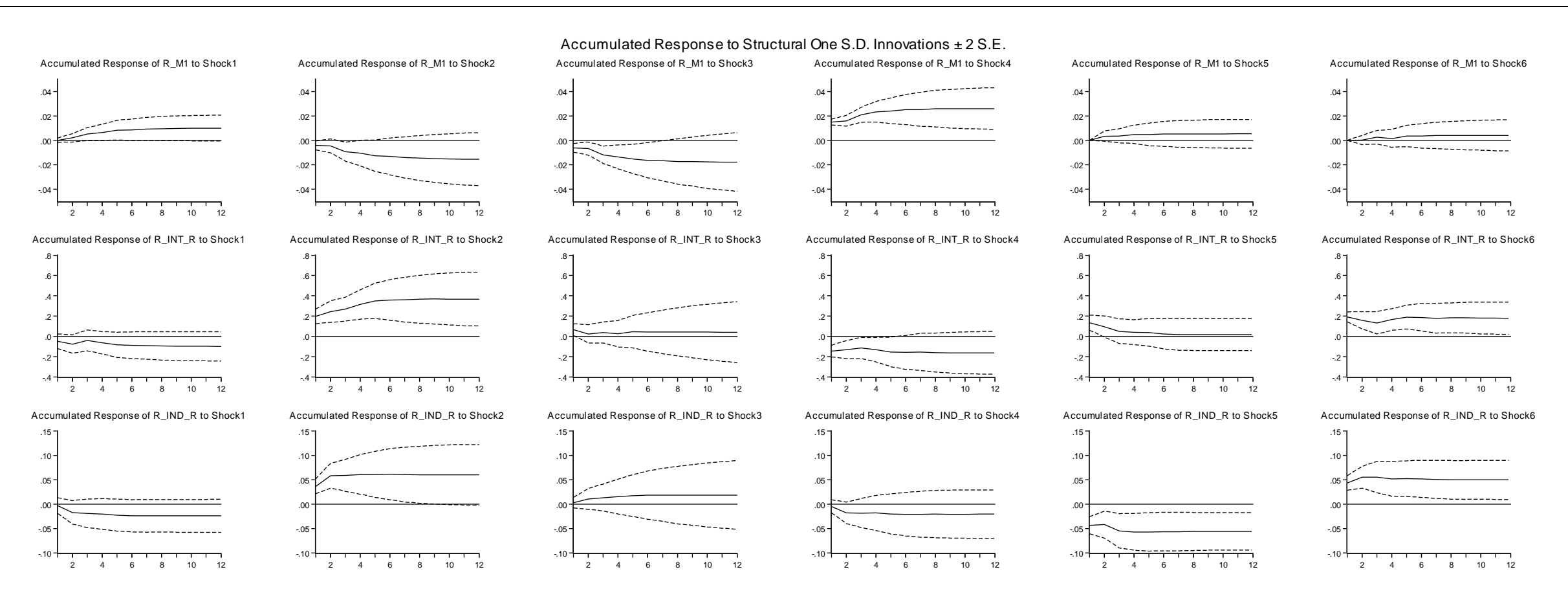

Note: Shocks 1, 2, 3, 4, 5 and 6 refer to shocks from global economic activity, gdp, inflation, money supply, interest rates and stock market, respectively. 


\section{Tables}

Table 1: Unit root tests

\begin{tabular}{|c|c|c|c|c|c|}
\hline & & $\mathrm{ADF}$ & prob. & PP & prob. \\
\hline & GEA & -8.874 & 0.000 & -8.907 & 0.000 \\
\hline \multirow[t]{6}{*}{ UK } & R_Y & -5.726 & 0.000 & -5.848 & 0.000 \\
\hline & R_CPI & -2.673 & 0.084 & -8.616 & 0.000 \\
\hline & R_GOV & -9.821 & 0.000 & -9.821 & 0.000 \\
\hline & R_M1 & -9.310 & 0.000 & -9.299 & 0.000 \\
\hline & R_INT & -4.936 & 0.000 & -4.936 & 0.000 \\
\hline & R_IND & -7.130 & 0.000 & -7.146 & 0.000 \\
\hline \multirow[t]{6}{*}{ Germany } & R_Y & -6.482 & 0.000 & -6.511 & 0.000 \\
\hline & R_CPI & -5.595 & 0.000 & -5.606 & 0.000 \\
\hline & R_GOV & -11.929 & 0.000 & -12.157 & 0.000 \\
\hline & R_M1 & -6.890 & 0.000 & -6.890 & 0.000 \\
\hline & R_INT & -4.797 & 0.000 & -4.797 & 0.000 \\
\hline & R_IND & -7.157 & 0.000 & -7.166 & 0.000 \\
\hline \multirow[t]{6}{*}{ US } & R_Y & -4.710 & 0.000 & -4.710 & 0.000 \\
\hline & R_CPI & -2.614 & 0.095 & -3.227 & 0.022 \\
\hline & R_GOV & -8.794 & 0.000 & -8.791 & 0.000 \\
\hline & R_M1 & -3.345 & 0.016 & -7.502 & 0.000 \\
\hline & R_INT & -8.852 & 0.000 & -8.916 & 0.000 \\
\hline & R_IND & -6.960 & 0.000 & -7.036 & 0.000 \\
\hline
\end{tabular}

Table 2: Optimal lag length - AIC

\begin{tabular}{crrr}
\hline Lag & UK & Germany & \multicolumn{1}{c}{ US } \\
\hline 0 & -24.9394 & -23.6284 & -26.8774 \\
1 & -25.9209 & -24.4782 & -27.9380 \\
2 & $-26.2863^{*}$ & $-24.8907^{*}$ & $-28.2971^{*}$ \\
3 & -26.1581 & -24.4877 & -28.2539 \\
4 & -26.2285 & -24.3190 & -28.0156 \\
\hline \multicolumn{4}{l}{ *Denotes optimal lag length } \\
\hline
\end{tabular}


Table 3: VAR Residual Portmanteau Tests for Autocorrelations

\begin{tabular}{ccrlrlrl}
\hline Lags & \multicolumn{1}{c}{ df } & \multicolumn{2}{c}{ UK } & \multicolumn{2}{c}{ Germany } & \multicolumn{2}{c}{ US } \\
\hline & & Q-Stat & Prob. & Q-Stat & \multicolumn{1}{c}{ Prob. } & \multicolumn{1}{c}{ Q-Stat } & Prob. \\
\hline 1 & NA* $^{*}$ & 15.07647 & NA* $^{*}$ & 15.87062 & NA* & 22.09707 & NA* $^{*}$ \\
2 & NA* $^{*}$ & 43.49633 & NA* $^{*}$ & 34.19935 & NA* $^{*}$ & 44.21211 & NA* $^{*}$ \\
3 & 49 & 55.85724 & 0.2328 & 57.62205 & 0.1864 & 60.99936 & 0.1167 \\
4 & 98 & 114.3761 & 0.1235 & 112.6434 & 0.1479 & 107.9626 & 0.2308 \\
5 & 147 & 168.2189 & 0.1110 & 160.7684 & 0.2067 & 164.8312 & 0.1493 \\
6 & 196 & 220.4298 & 0.1113 & 219.5989 & 0.1189 & 216.3948 & 0.1515 \\
7 & 245 & 270.0058 & 0.1306 & 259.4142 & 0.2518 & 270.5263 & 0.1261 \\
8 & 294 & 321.5324 & 0.1294 & 315.8406 & 0.1823 & 322.3796 & 0.1226 \\
9 & 343 & 376.7101 & 0.1016 & 369.3586 & 0.157 & 358.1522 & 0.2757 \\
10 & 392 & 417.3177 & 0.1816 & 408.286 & 0.2751 & 406.161 & 0.3003 \\
11 & 441 & 446.401 & 0.4194 & 450.164 & 0.3711 & 440.1045 & 0.5031 \\
12 & 490 & 485.286 & 0.5516 & 488.3014 & 0.5132 & 476.0297 & 0.6661 \\
\hline
\end{tabular}

*The test is valid only for lags larger than the VAR lag order.

$\mathrm{df}$ is degrees of freedom for (approximate) chi-square distribution

Table 4: VAR Residual Serial Correlation LM Tests

\begin{tabular}{cccrcrc}
\hline Lags & \multicolumn{2}{c}{ UK } & \multicolumn{2}{c}{ Germany } & \multicolumn{2}{c}{ US } \\
\hline & LM-Stat & \multicolumn{1}{c}{ Prob } & \multicolumn{1}{c}{ LM-Stat } & Prob & \multicolumn{1}{c}{ LM-Stat } & Prob \\
\hline 1 & 61.74404 & 0.1045 & 45.89823 & 0.5996 & 53.92253 & 0.2917 \\
2 & 58.66905 & 0.1622 & 49.94493 & 0.4356 & 56.9677 & 0.2028 \\
3 & 54.61245 & 0.2698 & 57.56752 & 0.1878 & 48.26431 & 0.5029 \\
4 & 55.56965 & 0.2411 & 45.06082 & 0.6335 & 43.32297 & 0.7017 \\
5 & 52.25551 & 0.3487 & 50.44987 & 0.4159 & 60.86576 & 0.1191 \\
6 & 59.89797 & 0.1368 & 39.97021 & 0.8177 & 41.66421 & 0.7622 \\
7 & 43.31528 & 0.7019 & 44.828 & 0.6429 & 52.83771 & 0.3282 \\
8 & 57.20676 & 0.1967 & 63.15657 & 0.0842 & 53.7728 & 0.2966 \\
9 & 56.88338 & 0.205 & 60.79706 & 0.1203 & 41.87293 & 0.7549 \\
10 & 45.95772 & 0.5972 & 54.09453 & 0.2862 & 58.35239 & 0.1693 \\
11 & 36.8566 & 0.8992 & 50.43688 & 0.4164 & 43.25518 & 0.7042 \\
12 & 56.6367 & 0.2115 & 47.1313 & 0.5492 & 46.63132 & 0.5697 \\
\hline Probabilities from chi-square with 49 df & & & \\
\hline \multicolumn{7}{c}{ firny }
\end{tabular}

Table 5: White Heteroscedasticity test

\begin{tabular}{lrrr}
\hline & \multicolumn{1}{c}{ UK } & Germany & \multicolumn{1}{c}{ US } \\
\hline Chi-sq & 861.2179 & 854.0547 & 856.5471 \\
df & 812 & 812 & 812 \\
Prob. & 0.1123 & 0.1486 & 0.1351 \\
\hline
\end{tabular}


Table 6: SVAR results - Contemporaneous coefficients

\begin{tabular}{crrr}
\hline Coefficient & \multicolumn{1}{c}{ UK } & Germany & \multicolumn{1}{c}{ US } \\
\hline$\alpha_{11}$ & $1.40527^{*}$ & $1.5893^{*}$ & $1.49954^{*}$ \\
$\alpha_{21}$ & 0.00066 & -0.0001 & -0.00024 \\
$\alpha_{22}$ & $0.00607^{*}$ & $0.0081^{*}$ & $0.00550^{*}$ \\
$\alpha_{31}$ & $0.00064^{*}$ & 0.0000 & 0.00008 \\
$\alpha_{32}$ & $0.17761^{*}$ & $0.1127^{*}$ & $0.07827^{*}$ \\
$\alpha_{33}$ & $0.00229^{*}$ & $0.0032^{*}$ & $0.00109^{*}$ \\
$\alpha_{42}$ & -0.53373 & -0.3913 & $0.80571^{*}$ \\
$\alpha_{43}$ & $-4.74495^{*}$ & $-1.1993^{*}$ & 0.42261 \\
$\alpha_{44}$ & $0.02536^{*}$ & $0.0177^{*}$ & $0.01111^{*}$ \\
$\alpha_{52}$ & 0.11185 & -0.0796 & $-0.80501^{*}$ \\
$\alpha_{53}$ & -1.39260 & $-3.2522^{*}$ & $-3.96834^{*}$ \\
$\alpha_{54}$ & -0.00122 & 0.0682 & 0.25296 \\
$\alpha_{55}$ & $0.02162^{*}$ & $0.0206^{*}$ & $0.01436^{*}$ \\
$\alpha_{61}$ & 0.01037 & $-0.0225^{*}$ & -0.01388 \\
$\alpha_{64}$ & $-3.32641^{*}$ & -0.2361 & 3.47329 \\
$\alpha_{65}$ & -0.51400 & $-1.4746^{*}$ & $-2.13638^{*}$ \\
$\alpha_{66}$ & $0.09442^{*}$ & $0.0820^{*}$ & $0.22182^{*}$ \\
$\alpha_{71}$ & -0.00469 & -0.0077 & 0.00161 \\
$\alpha_{72}$ & 1.50874 & $2.6297^{*}$ & $4.29761^{*}$ \\
$\alpha_{73}$ & 3.35597 & 0.8072 & -2.58190 \\
$\alpha_{74}$ & -0.31411 & -0.3748 & 0.05437 \\
$\alpha_{75}$ & 0.13110 & -0.2192 & -0.11259 \\
$\alpha_{76}$ & 0.08312 & -0.0373 & 0.04547 \\
$\alpha_{77}$ & $0.06005^{*}$ & $0.0901^{*}$ & $0.06127^{*}$ \\
\hline$*$ significant & & & \\
$5 \% 1$ & & &
\end{tabular}

